\title{
THE IMPACT OF SYRIAN REFUGEE CRISIS ON NEIGHBORING COUNTRIES
}

\author{
M. Hawamdeh, A. Al-Qteishat \\ Peoples' Friendship University of Russia (RUDN University) \\ Miklukho-Maklaya str. 6, Moscow, Russian Federation, 117198
}

\begin{abstract}
This article discusses the impact of short migration in Syria on neighboring countries. Since the begging of the civil war in Syria an exodus in large numbers has emerged. The turmoil and violence have caused mass migration to destinations both within the region and beyond.

The article discusses the political, social and economic effects of these crises on the regional security in the Middle East and beyond. Refugee crisis provokes many difficulties in receiving countries and living conditions of refugees are often questionable due to difficult humanitarian situation. The article analyzes the challenge to the neighboring countries of Syria (Jordan, Turkey, Lebanon and Iraq), that has been hosted more than five million forced refugees according to UN last statistics.

It is concluded that The Syrian refugee crisis remains one of the biggest problems facing the Middle East. It is more prone to more humanitarian and political problems, especially as it is a crisis of chaos, turmoil and protracted conflicts in the region.
\end{abstract}

Key words: Middle East, refugee crisis, Syria, Civil war in Syria, neighboring countries, The UN Refugee Agency, Political stability

In addition to the collapse of the Syrian state and the outbreak of a domestic civil war that claimed more than 300,000 lives, the Syrian crisis has led to a complicated demographic situation. According to UN statistics, more than 5 million people are internally displaced within Syria and about the same number are refugees outside of Syria, either hosted by the neighboring countries or stuck on the border between the countries.

The risk of a demographic crisis growing worse increases when it occurs on a territory with weakened social and governmental systems. The regional societies appear to be a mixture of ethnicities, religions, and sects. Suffering from multiple economic complications caused by the influx of refugees from across the border, a lot of people in the region are forced to live below the poverty line. Feeding on peoples' fear and despair, extremism and terrorism thrive in areas where violence seems to be the norm. Terrorist groups in the region take advantage of the ideal conditions to expand and recruit new members, while the number of refugees and displaced persons in countries with failed political and economic systems continues to soar.

Since the beginning of the crisis, there has been an incessant flow of refugees into neighboring countries. However, as the conflict grew more intense and its geographical area expanded, the number of refugees kept escalating as their directions of movement diversified. During the early stages of the conflict, the range of refugee migration remained rather limited. According to the United Nations High Commissioner for 
Refugees (UNHCR), shortly after the beginning of the war, an estimated 120,000 Syrian refugees fled to Jordan, Lebanon, Turkey and Iraq [5].

As the war progressed and the number of affected cities grew, millions of Syrian residents fled the country in what amounted to a mass exodus. According to the UNHCR report on 15 July 2015, the number of refugees fleeing the area of conflict to neighboring countries exceeded 4.72 million.

By the end of 2014, the number of people forcibly displaced around the world reached 59.5 million compared to 51.2 million people in 2013 , and 37.5 million people ten years ago. The rate of increase in 2013 is the highest ever, mainly due to the accelerated pace of displacement since early 2011 when the war in Syria broke out.

\section{MAP OF THE DISTRIBUTION OF SYRIAN REFUGEES IN THE REGION}

The vast majority of Syrian refugees are hosted by neighboring countries: Turkey, Lebanon, Jordan, Iraq and Egypt. The number of refugees these countries receive varies significantly. According to the UN High Commissioner for Refugees (UNHCR) in midJuly 2015, Turkey was the largest host country with 1.8 million registered refugees, which constitutes about $45 \%$ of the total number of Syrian refugees in the region. Lebanon, with 1.2 million Syrians, ranked second, followed by Jordan with 630,000, Iraq with 250,000, and Egypt with 133,000 displaced residents of Syria. Various North African countries also hosted about 24 thousand Syrian refugees [6]. About 270,000 Syrians are seeking asylum in Europe and other countries, among them are thousands of whom have been resettled from Syria's Middle Eastern neighbors [8].

\section{Turkey}

Hosting nearly half of the displaced persons (DPs) from Syria, Turkey is the largest single recipient of refugees in the region. By the end of May 2015, the number of Syrian refugees registered in Turkey reached 1.76 million, according to official Turkish statistics. The EU Civil Protection and Humanitarian Aid Operations also counted over 1.7 Syrian refugees registered in Turkey - a definite increase from the beginning of 2014, — which makes Turkey the largest host country in the world.

The infrastructure and development of neighboring countries - Turkey in particular - has been negatively affected by the influx of Syrian refugees, as they are obliged to provide long-term accommodation, healthcare and educational opportunities for those seeking asylum on their territory. Therefore, a "temporary protection system" based on EU directives on mass displacement has been introduced. It includes the right to stay in Turkey until a more permanent solution is found. However, it does not allow Syrian expatriates access to the asylum system provided by the Office of the United Nations High Commissioner for Refugees, nor does it grant the right to work [7].

Accordingly, Ankara provides temporary asylum to anyone crossing the border without a passport, but on the condition that they reside in a refugee camp. However, many Syrians managed to walk around this condition by crossing the border illegally, while others entered with a passport but exceeded their three-month-stay period. Stationed in Turkish cities, they put pressure on the labor market and represent a social and security burden for Turkish citizens. 


\section{Jordan}

According to the UNHCR, Jordan has received 700,000 refugees, while the Jordanian government estimates place the total refugee count including unregistered migrants (about 531,000) and Syrians living in Jordan before the start of the Syrian crisis $(700,000)$ at over 1.5 million. The Syrian refugees currently constitute $21 \%$ of Jordan's total population. Most of them are unable to return to their homes. Approximately $20 \%$ of Jordanian DPs are placed in refugee camps, while the rest were able to find shelter in cities and rural areas throughout the Kingdom, Amman and the governorates of Irbid and Mafraq hosting more than three-quarters of them [2].

It is evident that the unprecedented influx of Syrian refugees to Jordan is going to cause social and economic instability. There have been growing concerns among the local population that the Syrian refugees staying in Jordan for an extended period of time might want to settle there permanently and further damage the already troubled demographic situation. As the Jordanians' prior experience with Palestinian refugees has demonstrated, the longer the Syrian refugees stay in Jordan, the greater their chances for permanent settlement.

In addition, the influx of refugees onto the Jordanian territory presents a serious security threat. The transformation of the Jordanian border into a war zone increases the chances of infiltration of dangerous elements. The security situation is severely aggravated, as crime rates in cities spike and civilians become exposed to terrorist activities.

Beyond a doubt, hosting over a million Syrian refugees, which has led to an increase in population by $7-9 \%$, is making a heavy impact on the Jordanian economy. The influx of refugees has put pressure on the country's resources and infrastructure and maximized the budget deficit, causing rent and food prices to rise. Large numbers of Jordanians looking for jobs is aggravating the employment situation by creating a job deficit leading to wage reduction. Moreover, the Jordanian economy has been largely affected by the collapse in Syria. As all trade activities between the two countries have been suspended, Jordan has lost the Syrian market, and Turkey and Europe have lost the crucial Syrian trade route, which had to be replaced by a route through Iraq.

To provide accommodation for the displaced Syrians, Jordan has set up the Zaatari camp for refugees near the city of Mafraq, next to another camp near Zarqa. As incoming Syrians keep absorbing Jordanian space, resources and jobs, tensions with the locals continue to grow. As a result Jordanian authorities have tightened control over the refugee population, taking steps to restrict their movement within the country [4].

\section{Lebanon}

Lebanon ranks second in the number of Syrian refugees received and first in terms of the damage to its demographic situation. According to the UNHCR, about 1.2 million refugees have fled from Syria to Lebanon, or, according to the Lebanese government's sources, their number have amassed to 1.8 million.

Lebanese economy, overall greatly dependent on Syria and therefore experiencing a general downturn, has been further weakened by the influx of Syrian refugees. 
The obligation to employ the displaced has dealt a heavy blow on Lebanese labor market. A surge of refugees seeking employment and offering cheap labor has led to significant wage reduction and lower standards of living for the Lebanese, while the tensions between the two countries have reached a historical peak.

Furthermore, over a million Syrian DPs are negatively impacting Lebanon's infrastructure. Being a huge financial burden to the government, which lacks funding to meet the demands of the desperate refugee masses, Syrian expatriates have significantly worsened the budget deficit. As the refugee influx has increased the demand for Lebanon's already scarce resources, the government is unable to provide an adequate supply of food and water [3].

Another threat emanating from the refuge influx is that of national security: refugee camps may become the breeding ground for the spread of terrorism. Extremist groups may recruit new volunteers from the conflicting parties on both sides of the Syrian border to engage in terrorist activities, thus jeopardizing Lebanon's home security.

Consequently, in order to ease the economic pressure, protect the infrastructure and ensure safety, the Lebanese government has stopped receiving new refugees and encouraged the current refugees to return to their country. Lebanon also calls for international assistance to help deal with the refugee crisis. A few neighboring Arab countries, the United States and some EU members share of the costs of hosting the refugees through their humanitarian assistance programs.

\section{Egypt}

Since the beginning of the conflict, Egypt has been one of the main recipients of Syrian refugees. According to the UNHCR, Egypt hosts some 132,000 Syrians; the Egyptian Foreign Ministry, however, estimates the number of Syrian refugees at around 320,000. There are no refugee camps in Egypt. The Syrians live in rented homes, and they themselves provide adequate sustenance either through work or through remittances from relatives outside Egypt. Refugees who do not have such resources are supported by charities that offer shelter, food, clothing and financial assistance. However, finding suitable housing for Syrian families in Egypt has been a major problem.

In 2012, the Egyptian government adopted a republican decree promoting equal treatment of refugees. Therefore, immediately after the civil war in Syria began, the refugees arriving in Egypt were warmly welcomed. However, since June 2013, as a result of political changes in Egypt and the escalation of violence following the coup-d'état, the new Egyptian government has started to adopt tougher policies towards the Syrian refugees. As a new wave of social and political upheaval in Egypt brought hostility toward resident Syrians, hundreds of refugees left.

As a result of new restrictions imposed by the interim government on the Syrians and growing tensions with Egyptian residents, a lot of refugees viewed Egypt as a crossing point on their way to a more friendly country. Most of them refused to register at the UNHCR office in Egypt, hoping to resettle in European countries, often illegally. As desperate Syrian refugees were leaving Egypt trying to reach a European destination by sea in boats not safe for sailing, many lives were put at risk [1]. 


\section{Essentially, while adapting to new conditions in host countries, Syrian refugees have to face the following challenges:}

1. Unfavorable attitude from host nations. This does not hold true for all host countries. Certain states, in cooperation with international organizations, welcomed refugees and established conditions necessary for their reception, providing shelter and services for asylum seekers. However, the amount of resources in recipient countries differs. A number of countries have adopted restrictive policies and created difficult conditions for the displaced in order to prevent them from becoming permanent residents, fearing that refugees may use up their already limited resources. These countries have been subject to criticism by the global community and urged to ease the restrictions and provide asylum for those who need it.

2. Poor living conditions. Most refugees live in crowded and unsanitary settlements which lack many basic facilities and services. Despite international plans to establish healthcare and education centers and institutions, the scarcity of resources and still increasing number of DPs prevent these plans from being implemented.

3. Integration challenges. Even if refugees succeed in obtaining legal asylum, the chances of successful integration in local communities are low. Since most Syrian refugees end up relocating to neighboring countries, whose hosting communities are mostly poor themselves and lack a reliable legal structure to deal with this type of crisis, they are met with hostility by the local population.

4. Lack of proper funding. The United Nations estimates the cost of humanitarian and development requirements related to the Syrian crisis at about 5.5 billion dollars. The crisis stakeholders received only about a quarter of the amount, which was reflected in the services provided to refugees.

5. Education. With children being the second largest age category of Syrian refugees, more than a million children are currently not receiving any education. Thus Syria is likely to leave a whole generation uneducated and unable to provide a living, which is going to be an unprecedented national disaster.

\section{CONCLUSION}

The Syrian refugee crisis remains one of the biggest calamities in the modern Middle East. Just like the Palestinian refugee crises, which had lasted for longer than a decade, causing confusion, turmoil and prolonged conflicts, the current refugee crisis provoked by the Syrian Civil war slid the Middle East into chaos and hostility on ethnic, religious and sectarian grounds.

\section{REFERENCES}

[1] Atef A.H. The Syrians in Egypt: A Station in the Journey of Seeking an Opportunity for Stability. BBC. 03.05.2014. Available from: http://www.bbc.com/arabic/middleeast/2014/03/140318_ syrians_in_egypt. Accessed: 01.08.2018 (In Arab.).

[2] The Syrian Refugee Crisis in Jordan. Carnegie Middle East Center. 21.09.2015. Available from: http://carnegie-mec.org/2015/09/21/ar-pub-61296. Accessed: 01.08.2018 (In Arab.). 
[3] Action Plan: The Syrian Refugee Crisis. ILO. 2018. Available from: http://www.ilo.org/beirut/ areasofwork/syrian-refugee-crisis/lang--ar/index.htm. Accessed: 01.08.2018 (In Arab.).

[4] Jordan Response Plan for the Syria Crisis 2018-2020 (Final) and Annex. Available from: http://www.jrpsc.org/. Accessed: 01.08.2018.

[5] Mahmood A. A Dynamic Demography of the Syrian Refugee Crises in Neighboring Countries. ARAA. 08.02.2018. Available from: http://araa.sa/index.php?view=article\&id=3421:2015-0802-13-33-44\&Itemid=172\&option=com_content. Accessed: 01.08.2018 (In Arab.).

[6] Orkan O. The Situation of Syrian Refugees in Neighboring Countries. Alsouria.net. Available from: https://www.alsouria.net/content/\%D9\%88\%D8\%B6\%. Accessed: 01.08.2018 (In Arab.).

[7] The Syrian Refugee Crisis and its Impact on Turkey. Adwhit Lojistik. Available from: https://www.adwhit.com/\%D8\%AA \%D8\%B1\%D9\%83\%D9\%8A\%D8\%A7/\%D8\%A3\%D8\% B2\%D9\%. Accessed: 01.08.2018 (In Arab.).

[8] The UN Refugee Agency. Available from: http://www.unhcr.org/ar/. Accessed: 01.08.2018.

DOI: $10.22363 / 2313-1438-2018-20-4-548-554$

\title{
ВЛИЯНИЕ КРИЗИСА БЕЖЕНЦЕВ В СИРИИ НА СОСЕДНИЕ СТРАНЫ
}

\author{
М. Хавамдех, А. Аль Ктеишат \\ Российский университет дружбы народов \\ ул. Миклухо-Маклая, 6, Москва, Россия, 117198
}

В данной статье рассматривается влияние массовой вынужденной миграции из Сирии на соседние страны. С начала гражданской войны в Сирии начался массовый исход беженцев из этой страны. Беспорядки и насилие привели к массовой миграции как внутри региона, так и за его пределы. В статье рассматриваются политические, социальные и экономические последствия миграционного кризиса для региональной безопасности на Ближнем Востоке и за его пределами, а также трудности, связанные с адаптацией сирийских мигрантов и беженцев в странах приема, их условиями жизни и гуманитарным положением.

Кризис беженцев является серьезным вызовом для соседних с Сирией стран (Иордании, Турции, Ливана и Ирака), которые, согласно последним статистическим данным ООН, приняли более пяти миллионов беженцев.

Авторами сделан вывод о том, что кризис беженцев в Сирии остается одной из самых серьезных и актуальных проблем, стоящих перед Ближним Востоком. В связи с затяжным характером сирийского конфликта данный кризис является длительным и труднопредсказуемым.

Ключевые слова: Ближний Восток, кризис беженцев, Сирия, гражданская война в Сирии, Агентство ООН по делам беженцев, политическая стабильность

\section{Сведения об авторах:}

Хавамдех Мазен Хуссен Фалах - аспирант кафедры сравнительной политологии Российского университета дружбы народов (ORCID ID: 0000-0003-2695-5879) (e-mail: mazen_1616@yahoo.com).

Аль Ктеишат Ахмад Сахер Ахмад - аспирант кафедры сравнительной политологии Российского университета дружбы народов (ORCID ID: 0000-0002-3650-5460) (e-mail: ahmad_qteishat@hotmail.com). 


\section{Information about the authors:}

Mazen Hussien Faleh Hawamdeh - Postgraduate Student of the Department of Comparative Politics, Peoples' Friendship University of Russia (RUDN University) (Russian Federation) (ORCID ID: 0000-0003-4463-2766) (e-mail: mazen_1616@yahoo.com).

Ahmad Saher Ahmad Al-Qteishat - Postgraduate Student of the Department of Comparative Politics, Peoples' Friendship University of Russia (RUDN University) (Russian Federation) (ORCID ID: 0000-0003-3393-2210) (e-mail: ahmad_qteishat@hotmail.com).

Статья поступила в редакцию 20.08.2018.

Received 20.08.2018.

(C) Хавамдех М., Аль Ктеишат А., 2018. 